\title{
HABER
}

\section{TÜRKİYAT SOHBETLERİ 2013-2014}

\section{Müslüm YILMAZ*}

İstanbul Üniversitesi Türkiyat Araştırmaları Enstitüsü tarafından düzenlenen "Türkiyat Sohbetleri" adı altındaki aylık akademik toplantıların ikinci dönemi tamamlandı. Türk dili ve edebiyatı, Türk tarihi ve kültürü üzerine çalışmalarıyla tanınan değerli akademisyenlerin konuşmacı olarak katılımıyla gerçekleştirilen bu toplantılarla Türkiyat araştırmaları alanına önemli katkılar sağlandı.

Türkiyat Sohbetleri'nin 2013-2014 eğitim öğretim yılının ilk konuşmacısı, 31 Ekim 2013 tarihinde Enstitümüz öğretim üyelerinden Yrd. Doç. Dr. Ayna Askeroğlu Arslan'ın konuşmacı olarak katılımıyla gerçekleştirildi. Askeroğlu Arslan, görsel sunumlar eşliğinde gerçekleştirdiği “Ahıska Türkleri’nin Dünü ve Bugünü" başlıklı konuşmasında günümüz Türk Dünyası'nın kanayan yaralarından Ahıska Türkleri’nin meselelerini dile getirdi. dikkat çekti:

Yrd. Doç. Dr. Ayna Askeroğlu Arslan konuşmasında şu konulara

"Ahıska Türkleri, kasıtlı olarak bazı kesimlerce Mesket Türkleri ve İslamlaşmış Gürcüler olarak adlandırılmaktadır. Ahıska Bölgesi ve Türkleri, Dede Korkut Kitabı'nda da “Ahıska" isimiyle geçmektedir. Bu yanlış adlandırmalar vatanlarından sürülmüş olan Ahıska Türkleri'nin biliçli olarak milli benliklerini zedelemek için yapılmaktadır.

16. yüzyıldan 20. yüzyıl başlarına kadar Osmanlı Devleti sınırları içerisinde olan bu topraklar, Anadolu Türkleri'nin ayrılmaz bir parçası olarak varlığını devam ettirmiştir. Osmanlı Devleti'nin zayıflaması ile Ahıska Bölgesi Rus işgaline uğramıştır. Bolşevik İhtilali'inden sonra Ruslar genel bir politika değişikliğine gitmiş, Ahıska Türkleri'ne de kendi kaderlerini seçme hakkı tanımıştır. Ahıska Türkleri de Türkiye Cumhuriyeti'ne bağlanmak istemiştir. Bu kararı ilk başta kabul eden

\footnotetext{
* Arş. Gör. İstanbul Üniversitesi, Türkiyat Araştırmaları Enstitüsü, Türk Dili ve Edebiyatı Anabilim Dalı, muslum.yilmaz@istanbul.edu.tr
} 
Bolşevik Hükümeti, 1928 yılında kararından vaz geçerek, Ahısıka Türkleri'nin yaşadığı toprakları işgal etmiş, bölgeyi Moskova' ya bağladığını ilan etmiştir.

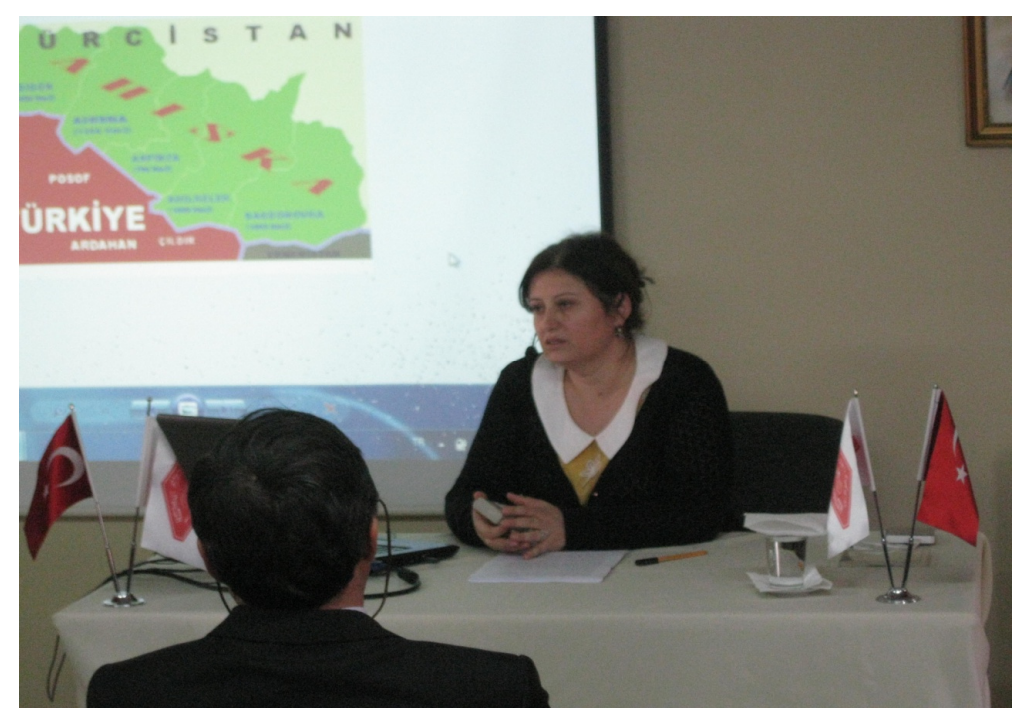

Sosyalist Rusya Başkanı Stalin, Gürcü olması nedeniyle Ahıska Bölgesi ile yakından ilgilenmiştir. Bölgede yaşayan Türkleri, Karadeniz çevresinden arındırma politikası benimsenmiştir. Bölgedeki Ahıska Türkü erkeklerinin 40.000'ini II. Dünya Savaşı sırasında trenlere bindirerek Almanlara karşı savaşmak üzere savaş bölgesine göndermiştir. Bu savaşta bilinçli bir kıyım yaşanmasına göz yuman Rus yönetimi, geride kalan kadın ve çocukları Kasım ayının zorlu kış şartlarında Batum Demiryolu inşasında çalıştırmıştır. Buradaki soğuk ve salgın hastalıklar yüzünden birçok Ahıskalı Müslüman-Türk hayatını kaybetmiştir. II. Dünya Savaşı'na gönderilen 40.000'i aşkın Ahıskalı'dan sadece 10.000'i hayatta kalabilmiştir. Geride kalan Ahıskalılar ise hayvanların taşındığı tren vagonlarına bindirilerek Kazakistan ve Özbekistan bozkırlarına yerleştirilmiştir. Bu yolculuk ve zorunlu sürgün 15 gün devam etmiş, sürgün esnasında yaşlı ve çocuklar hayatını kaybetmiştir. Yolculuk esnasında vefat eden yaklaşık 50.000 Ahıska Türkü'nün cesedi vagon kapıları açılarak giden trenlerden aşağı atılmıştır. Mezar yerleri bile belli olmayan Ahıskalılar için 1944 yılı tarihin "kara günü"dür. Boşaltılan Ahıska Bölgesi'ne ise yine bir proje dâhilinde Ermeniler yerleştirilmiştir. Bilinçli bir soykırıma maruz bırakılan Ahıskalılar vatansız olarak devamlı yaşadıkları bölgelerden sürülmüşlerdir. 
SSCB'nin 1989 yılında dağılmasından sonra yurtlarından sürülen milletlere geri dönüş hakkı verilmesine rağmen Ahıska Türkleri'nin bu hakkı kullanması engellenmiştir. Millî kimliklerini ve dinlerini değiştirme şartını kabul etmeyen Ahıska Türkleri'ne Turgut Özal döneminde Türkiye Cumhuriyeti kucak açmış ve ilk adım olarak 150 kadar aile Iğdır'a yerleştirilmiştir. $\mathrm{Bu}$ ailelere ayrıca vatandaşlık hakkı verilmiştir. Günümüzde vatan topraklarına hasret yaşayan Ahıska Türkleri, 800.000'i aşan nüfusuyla Kazakistan, Özbekistan, Kırgızistan, Türkiye, Amerika ve Rusya gibi ülkelerde dağınık bir şekilde yaşamaktadır. Ahıskalıların bu topraklardan sürülmesinin bir nedeni de Türkiye ile Orta Asya Türkleri arasında bir köprü oluşturmalarını engellemek içindir.

Vatansız Ahıska Türkleri ve dünya insanlık tarihi için 1944 sürgünü kara bir lekedir. Ahıska Türkleri'nin Türkiye ile Birleşmiş Milletlerden beklentisi, dünya insanlık tarihinin alnındaki kara lekeyi silmesi ve vatan hasreti çeken gurbetteki Ahıskalıların topraklarına geri dönmesinin sağlanmasıdır.

Türkiyat Sohbetleri'nin ikinci konuşması, 27 Kasım 2013 tarihinde İstanbul Medeniyet Üniversitesi Dil Bilimi Bölümü Öğretim Üyesi Yrd. Doç. Dr. Hakan Aydemir'in konuşmacı olarak katılımıyla gerçekleştirildi. Yrd. Doç. Dr. Hakan Aydemir, görsel sunumlar eşliğinde "Tohar-Türk İlişkileri ve Toharların Müslümanlaşması" başlıklı konuşmasında şu konulara temas etti:

Toharca, Hint-Avrupa dil ailesine mensup Doğu Türkistan'da kullanılmış, artık günümüzde kullanılmayan bir dildir. Bu dil, 8. yüzyıldan sonra Toharların Türkleşmesi ve Uygurlaşması ile zamanla tarih sahnesinden silinmiștir.

$\mathrm{Bu}$ topluluğun Uygurlular tarafından ortadan kaldırdığı yolundaki yanlış düşünce, batılı yazarlar tarafından ortaya atılmıştır. Orta Asya'da yaşayan bir Türk topluluğu asla diğer bir topluluğu yok etmemiş, sadece hükümlarlığı altına almıştır. Toharlar, 386 yılında ilk defa resmi olarak Türk devleti olan Tabgaç Devleti'nin hükümranlığ 1 altına girmiştir. 403 yılında da bu devlete vergi verdiklerini bilmekteyiz. 630 yılında bu tarım bölgesi, Göktürk Devleti'nin hakimiyeti altına girmiş, II. Göktürk Devleti döneminde Göktürkler, Toharların yaşadığı bölgelere askerî seferler düzenlemiştir.

$\mathrm{Bu}$ dönemde Toharlar kendi aralarında dillerini kullanarak Budist dini yaşantılarına devam etmiş, sonraki yüzyılarda Karahanlılar'ın yönetiminde yaşamışlardır. 
Kaşgarlı Mahmud'un Divânu Lügati't-Türk'ünde Karahanlıların içinde kendi aralarında başka dilleri kullanan boyların var olduğunu söylemesi, 12. yüzyılda yazılan Farsça bir kaynakta "Toğrak" adlı bir Karahanlı kabilesinden söz edilmesi ve bu "Toğrak" adının 9. yüzyılda Karabalgasun yazıtında Toharların ve yaşadıkları bölgenin adı olarak geçmesi, Toharların 12. yüzyılda hâlâ yaşadığının kanıtıdır.

Batılı dil bilimci ve tarihçilerin 8. yüzyılda Uygur Devleti'nin kurulması ile bu dil, tarih ve topluluk yok edilmiştir düşüncesinin doğru olmadığını, 10. ve 12. yüzyıllar arasında yazılmış Toharca metinler göstermektedir.

Tohar dili hakkında bilinen son metin 12. yüzyılda yazılmıştır. Bu metin Budist dini hakkındadır. Bu metinin dilinin kısmen bozuk olduğu dikkat çekmektedir. Toharlar 10. yüzyıldan itibaren İslamiyet'e girmeleriyle zamanla kendi dillerini aralarında daha az kullanmaya başlamış, Türkçe sosyal hayatın içine girmiştir. Zamanla bu topluluk Türkleşmiştir.

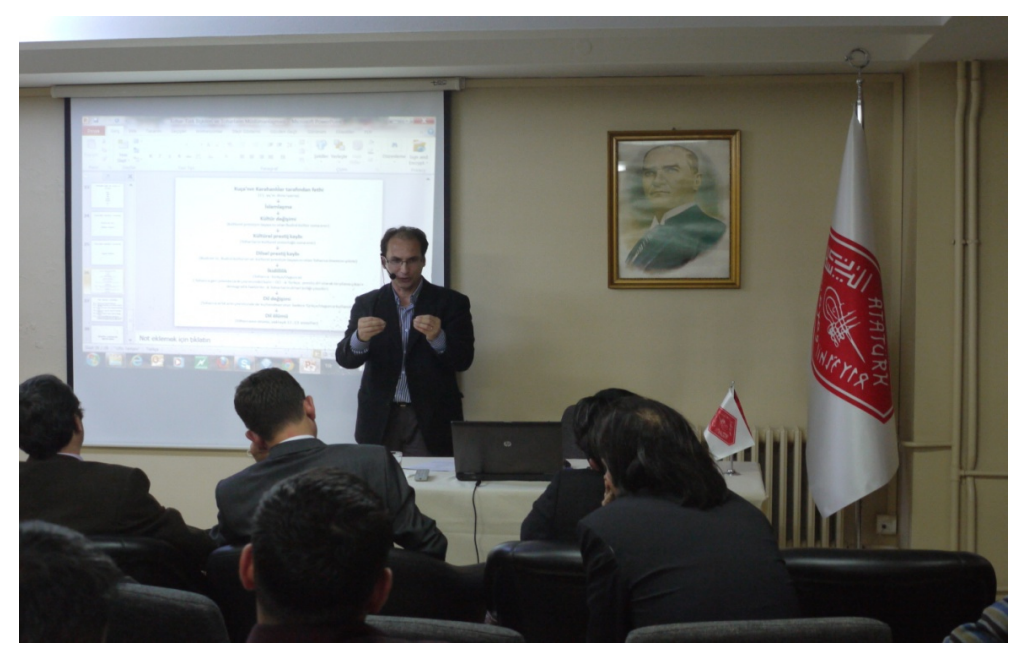

Türkiyat Sohbetleri'nin üçüncü konuşması, 25 Aralık 2013 tarihinde Boğaziçi Üniversitesi Tarih Bölümü Öğretim Üyesi Yrd. Doç. Dr. Yavuz Selim Karakışla'nın konuşmacı olarak katılımıyla gerçekleştirildi. Yrd. Doç. Dr. Yavuz Selim Karakışla belgeler eşliğinde "Arşivden Bir Belge: Osmanlı Belgeleri Üzerinden Gündelik Hayatın Tarihi (1839-1923)" başlıklı konuşmasında şu konulara temas etti:

"Osmanlı tarihi yazımı genellikle devlet üzerinden takip edilmektedir. Devletin gidişatına en büyük etki sosyal hayatta yaşanan 
hadiselerdir. Bu hadiseler arşiv belgelerine yansımıştır. Bu noktada Osmanlı Arşivleri'nde katolog taramak insanın ufkunu genişletmektedir. Bir dönemi bütün renkleriyle görmenizi sağlar. En küçük, anlamsız gelen bir olay, size günlük hayatın kalbinin nasıl attı̆̆ını gösterir. Bu açıdan dönemin gazeteleri de ana kaynaklardandır. Lakin ilk sayfalar siyasî, 3-4. sayfalar sosyal hayat hakkında size neler yaşandığını gösterir. Gazetenin çıkmadığı dönemlerde yine başvuracağınız yegâne kaynaklar arşiv belgeleridir. Bu çalışmalar sosyal hayatta yaşanan olayların daha iyi incelenmesini sağlayacaktır.

Batıdaki tarihçiler devletlerin tarihlerini inceledikten sonra her kavramın üzerine çalışmalar yapmışlardır. Koku tarihi, su tarihi, demir tarihi vs. gibi. Bizde de bu tarzda çalışmalar yapılmaya başlanmıştır

Devlet belgelerinde geçmeyen esnaf veya sosyal bir topluluk, o sınıfın olmadığını göstermez. Arşiv belgelerinde rastgele halktan biri yer almaz. Ne zaman bu kişiler devletle çatışır veya bir sürtüşme olursa bu durum belgelere yansır. Onun için belgelere en az suç işlemeden uzak duran çocuklar yansır. Belgelerin bir dili vardır. Bu dil devlet bürokrasisinin kullandığı dildir. Biz hep devletin tarihini yazıyoruz. Bu açıdan sosyal hayattaki olayların yansıdığı belgeler çok önemlidir.

Mehmet Fuat Köprülü' nün kurmuş olduğu bu kuruma gelmek benim için büyük bir onurdur. Bu onuru yaşamama vesile olan Enstitü yetkililerine teşekkür ederim."

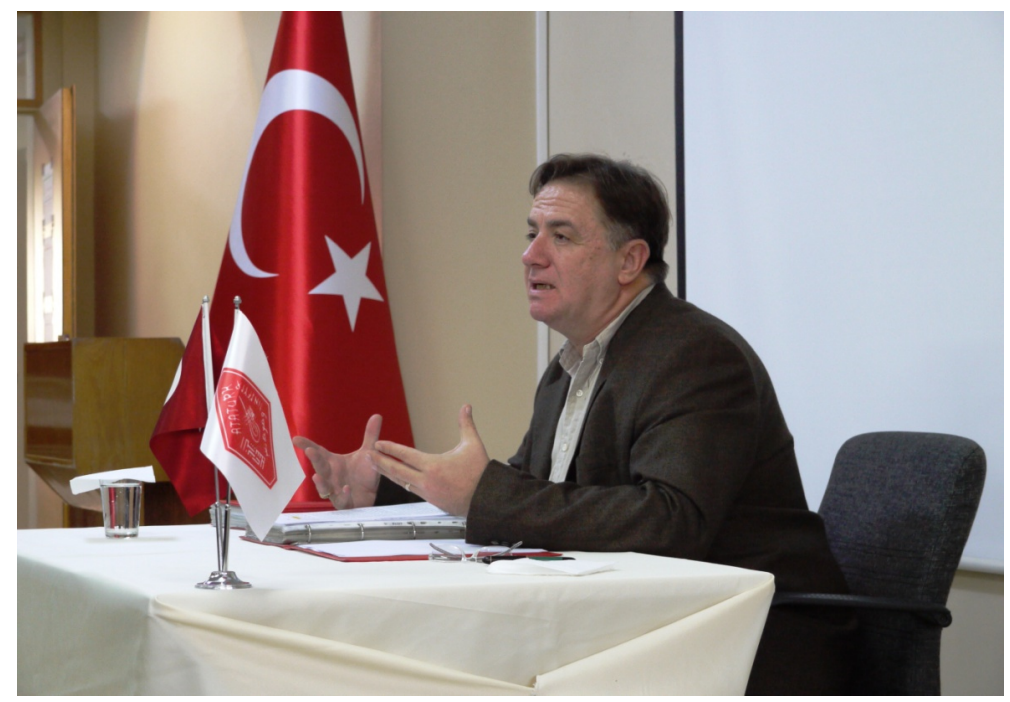


Türkiyat Sohbetleri'nin dördüncü konuşması, Mimar Sinan Üniversitesi Türk Dili ve Edebiyatı Bölümü Öğretim Üyesi Prof. Dr. Abdullah Uçman'ın katılımıyla gerçekleştirildi. Prof. Dr. Abdullah Uçman, "Hayat ve Edebiyat İlişkisi Üzerine" başlıklı konuşmasında şu konulara temas etti:

\section{Bir kitap okudum, hayatım değişti...}

Edebiyat, edeb kelimesinden geldiği için insanın ahlakına, yaşayışına doğrudan bir etkisi vardır. Edebiyat ile hayatı bir bütün olarak değerlendirmek gerekir. Bu bütünü birbirinden ayırmak mümkün değildir. Bazen bir söz, bir kelime veya bir eser insanın hayatını tamamen değiştirebilir. Bunu Yunus Emre, o veciz ifadesi ile iki mısrada özetlemiştir:

Söz ola kese savaşı

Söz ola kestire baş1

Edebiyat ve hayatın bir bütün olarak görülmesi açısından konuya birkaç örnek verecek olursak:

- Fatih'in ünlü şair ve veziri Ahmed Paşa, yaptığı bir hatadan dolayı sultanın emri ile zindana atılmış, zindandan yazdığı "Kerem" redifli kasidesiyle bir anda sultanın affına kavuşmuştur.

- Nef'i gibi kasidede döneminin en büyük üstadı, sivri diliyle yazdığ 1 hicviyelerle (siham-1 kaza) devlet erkânının gazabına uğramış, sonunda idam ettirilmiştir. Nef'i'nin sivri dili yüzünden kötü akıbetini dönemin şairleri bir beyitle dile getirmiştir:

Gökten nazîre indi Sihâm-1 Kazâ'sına

Nef'î diliyle uğradı Hakk'ın belâsına 


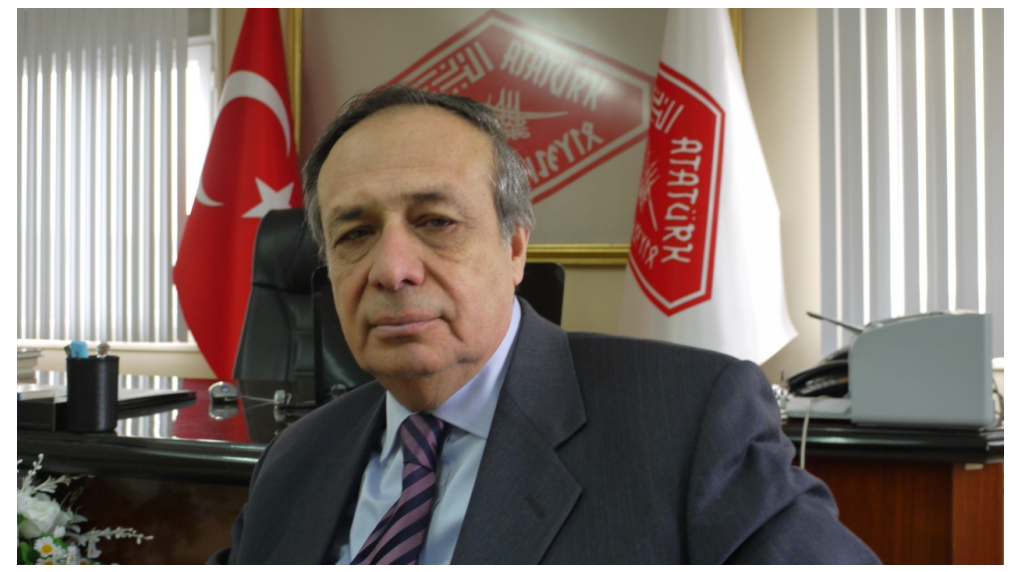

- Yine Kânûnî Sultan Süleyman dönemi şairlerinden Figânî, bir mecliste Mak(t)bul İbrahim Paşa'ya hitaben bir beyit söylemiş, bu beyit yüzünden Paşa tarafından idam ettirilmiştir.

- Namık Kemal'in yazdığı "Vatan Yahut Silistre" piyesi sahnelenince halk tarafından çok beğenilmiştir. Tiyatroyu izleyen halk, piyesi seyrettikten sonra yollara dökülüp "yaşasın vatan, yaşasın Namık Kemal" sloganları ile şehirde 3-4 gün yürümüştür. Bu olaylar artarak devam edince devlet bu işe müdahale etmiştir. Namık Kemal'in de yazılarının yayınlandığı İbret gazetesindeki birkaç yazar da bu işe dâhil edilerek, sözde bir mahkemede yargılanmış ve sürgüne mahkûm edilmiştir. Bugün ise Milli Eğitime bağlı mekânlarda sahnelenmesi sorun olmayan bir yapıt, bir dönem farklı etki uyandırmıştır.

- Hüseyin Rahmi, Mürebbiye adlı eserinde Fransız mürebbiyeleri eleştirir. Fransızlar İstanbul'u işgal ettiği yıllarda kendilerine hakaret edildiği iddiasıyla bu romanı toplattırmışlardı.

- Edebî bir eserdeki kahramanların kişiliğinden etkilenen okuyucular, kendi çocuklarına bu kahramanların isimlerini verdikleri görülür. 1970'li yıllarda Turan Oflazoğlu'nun IV. Murat adlı oyunu sahnelenmiştir. Bu oyun, İstanbul'da oynanmaya başlanınca çok büyük etki uyandırmıştır. Hatta bu dönemde doğan erkek çocuklara Murat isminin çok fazla verildiği görülür. $\mathrm{Bu}$ örnekleri çoğaltmak mümkündür. Özetle denilebilir ki bir eser insanın hayatını tamamen değiştirebilir. Abdullah Uçman'ın sözlerini Orhan Veli'nin bir şiiriyle tamamlamıştır. 
Ağlasam sesimi duyar mısınız,

Misralarımda;

Dokunabilir misiniz,

Gözyaşlarıma, ellerinizle?

Bilmezdim şarkıların bu kadar güzel,

Kelimelerinse kifayetsiz olduğunu

Bu derde düşmeden önce.

Bir yer var, biliyorum;

Her şeyi söylemek mümkün;

Epeyce yaklaşmışım, duyuyorum;

Anlatamiyorum...

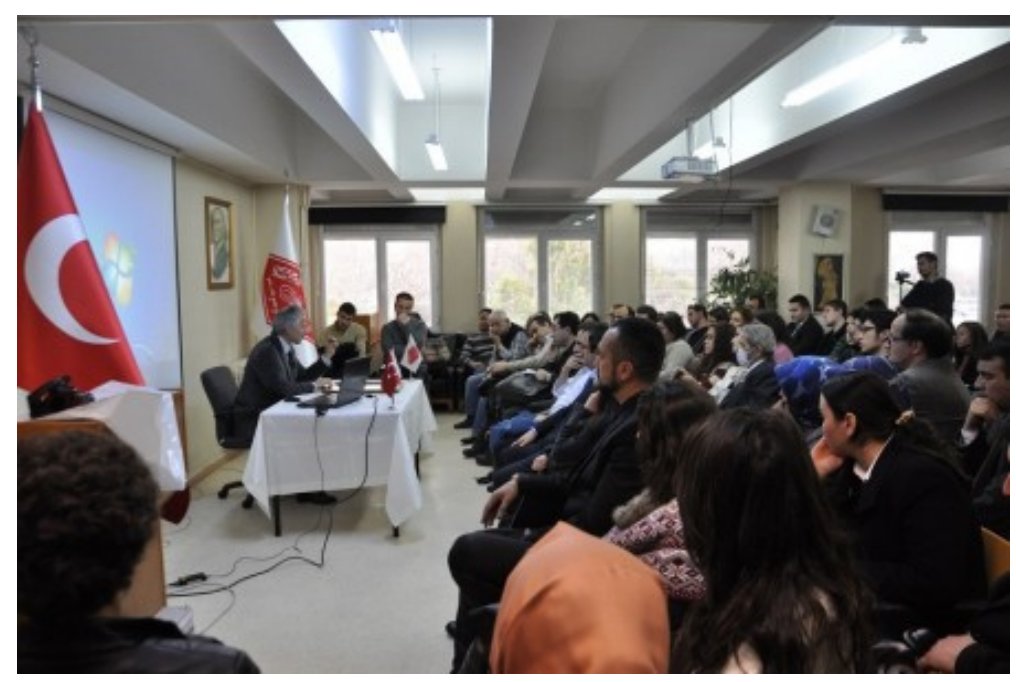

Türkiyat Sohbetleri'nin beşinci konuşması, 26 Şubat 2014 tarihinde

Türk Dil Kurumu Başkanı Prof. Dr. Mustafa S. Kaçalin'in konuşmacı olarak katılımıyla gerçekleştirildi. Prof. Dr. Mustafa S. Kaçalin "Kitâbiyât: Bibliyografya Üzerine" başlıklı konuşmasında şu konulara temas etti:

Bibliyografya çoğu zaman kitabın sonunda zorunlu olarak verilen bir liste olarak görülmektedir. Bir eseri hazırlarken en önemli bölüm aslında kaynakçadır. Eser hazırlanırken hangi eserlerden istifade edildiğini gösteren kaynakça, eseri hazırlayan müellifin dikkatini, konuya bakışını bize gösterir.

Bilgiye ulaşmak kadar bilgiye ulaşma metotu da son derece önemlidir. Bir konuyu araştırırken ilk önce o konuyla ilgili yapılmış çalışmaları tespit 
ederiz. Tespit ettiğimiz eserleri inceler kaynakçasına bakarız. Bilgi merkezi olan kütüphanelere uğramadan, araştırma yaptığımız konu ile ilgili alanda ne yapıldığını bilemeyiz. Kütüphane tasnif sistemlerinden olan Dewey, LC, bilinmeden iyi bir eser hazırlamak mümkün değildir. Bir çalışma yaparken yüzlerce kaynak görürsünüz, fakat bunlardan belli bir kaçı eseri hazırlamada ana kaynak olur.

Kaynakçada verilen kitapların baskı tarihleri, kütüphane kataloglama sistemi bilinmeden verildiğinde okuyucular basit hatalara düş̧ebilir. Kitabın baskı tarihi 1301 şeklinde yazılıyor. Bu tarih Hicrî mi yoksa Rûmî tarih mi? Aralarında iki sene fark olduğunu bilmeyen genç bir akademisyen bazı yanlışlara düşmekte, kitabın yazıldığı yılı kesin olarak tespit edemediği görülmektedir.

$\mathrm{Ne}$ yazık ki metin neşri ya da dil incelemeleri gibi eserler hazırlanırken başka bir yanlışa düşüldüğü de görülmektedir. Buna bir örnek verecek olursak, Nev'î'nin Netâyicü'l-fünûn adlı eserini yayına hazırlarken yalnız günümüz alfabesine aktarıp, dizin koymakla eseri tam anlamılla neşretmiş olamayız. Müellif çoğu zaman eserinde istifade ettiği kaynaklardan bahseder. Buna rağmen biz bu eserleri okuyup incelemezsek, müellifin konuya bakış açısına vâkıf olamadığımız için, eseri de hakkıyla anlamış olamayız. Bu yüzden hazırladığımız bu neşirde birçok hatalara düşebiliriz.

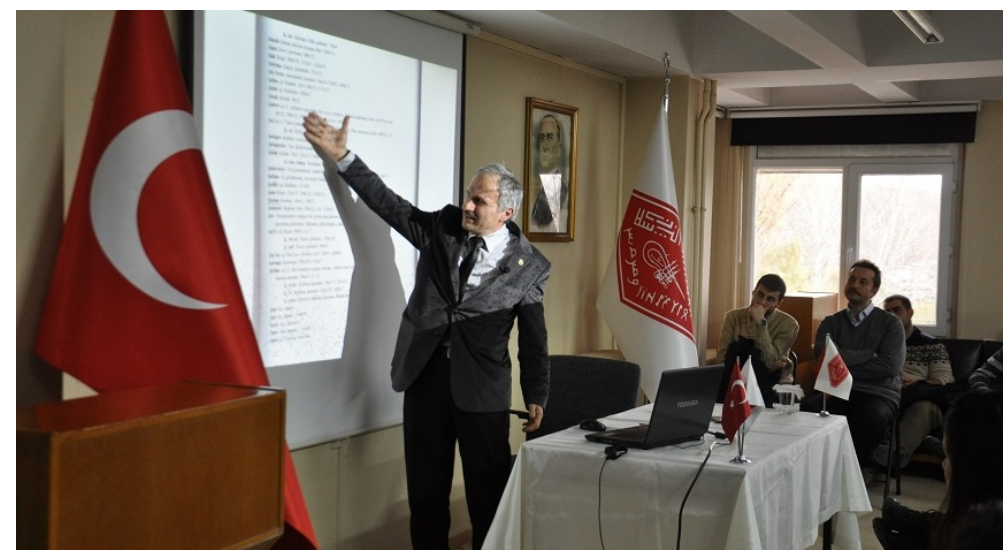

Bazı kaynakçalarda bir eserin ilk baskısı görülmeden sonraki baskılarının kullanıldığı da sıklıkla görülmektedir. Hâlbuki müellif ilk baskıda öne sürmüş olduğu tezleri, sonraki baskılarda değiştirebilir. İstifade edeceğiniz bir eserin 5. baskısını görmek, eseri hazırlayan "müellifin konuya bakış açısı şudur" demek anlamına gelmez. Müellifin ilk baskıda ortaya 
attı̆g görüşleri sonraki baskılarda nasıl değiştirmiş olduğuna dikkat etmek gerekir. Eseri telif eden kişi vefat ettikten sonra, eserin yeni yapılan baskılarında yer yer sadeleştirmeler, bazı değişiklikler yapılabilir veya bazı bölümler kısaltılır ya da tamamen çıkarılabilir. Ticarî kaygı ile yapılan bu neşirlerdeki hataları bilmeyen okuyucular bu eserden alıntı yapmakta, hatalar bir kartopu gibi zamanla büyüyüp çı̆̆ olmaktadır. İlmin iki ana esası vardır: Biri tecrübe yani birikim, diğeri hocadır. Hocanız yazdığınız eserin iz düşümüdür. Onun için hocalarımızdan hakkıyla istifade etmek gerekir.

Türkiyat Sohbetleri'nin altınc1 konuşması, Yunus Emre Enstitüsü'nün katkılarıyla 27 Mart 2014 tarihinde Eski Uygurca Sözlük Çalıştayı olarak yapıldı. Bu çalıştaya Prof. Dr. Klaus Röhrborn (Almanya) "Eski Uygurca Sözlüğünün Hazırlanmasında Bugüne Kadar Kullanılan Metotlar", Prof. Dr. Mehmet Ölmez (Yıldız Teknik Üniversitesi) "Eski Türkçe Sözlükler", Yrd. Doç. Dr. Murat Elmalı (İstanbul Üniversitesi ) "Eski Uygurca Çalışmaları ve Sözlük İhtiyacı" başlıklı tebliğleriyle bu alanda çalışan akademisyenlerin katılımıyla gerçekleştirildi.

Toplantıda Klaus Röhrborn, Eski Uygurca sözlük çalışmalarının tarihinden bahsederek söze başlamıştır. Buna göre ilk Uygurca sözlük, W. Bang ile A. von Gabain'in Türkische Turfan-Texte I-V için hazırladıkları Analytischer Index zu den fünf ersten Stücken der Türkischen Turfan-Texte adlı çalışmadır. (Bang, Willi / Annemarie von Gabain, Berlin 1931). Bu çalışmanın devamında Ahmet Caferoğlu'nun üç fasikül halinde hazırladığı Uygur Sözlüğ̈̈ gelmektedir (1934 ve sonrasi; genişletilmiş 2. bask1 1968).

Bu ilk çalışmalardan sonra A. von Gabain'in 1941'de yayımlanan grameri gelir (Alttürkische Grammatik. Mit Bibliographie, Lesestücken und Wörterverzeichnis, auch Neutürkisch. Leipzig; 2. bask1 1950; 3. bask1 1974). Gramerin sonunda yer alan sözlük konuyla ilgili en zengin ilk çalışmalar arasında gelmekte olup madde karşılıkları Almanca ve Türkçe olarak iki dillidir. 


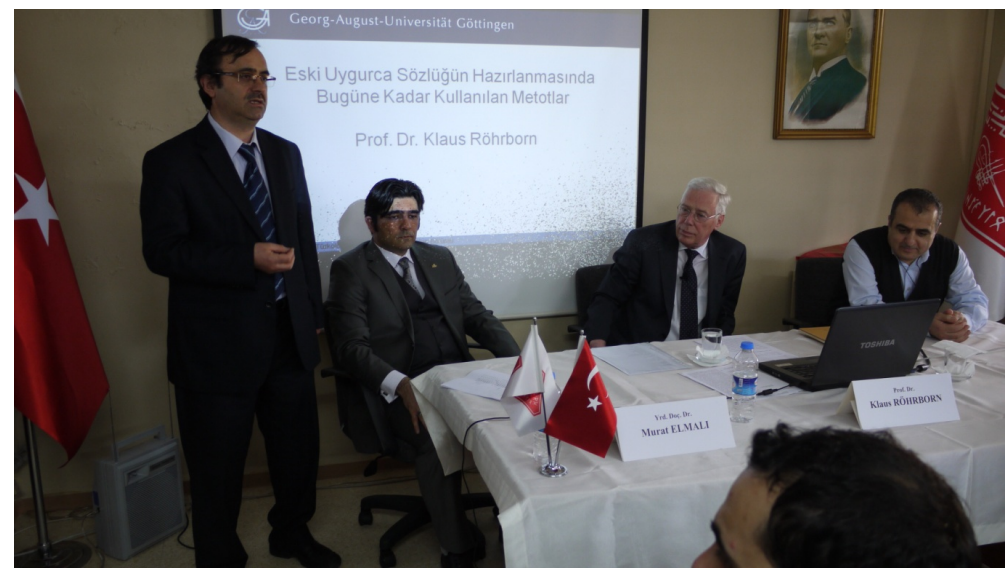

A. Von Gabain, ayrıntılı ve yeni bir Uygurca sözlükle ilgili çalışmalara başlamak üzere konuyla ilgili meslektaşlarıyla fikir alışverişlerinde bulunur. 19. yüzyılın başından itibaren İpek Yolu bölgesinde, bugünkü Turfan ve çevresinde bulunan Soğud ve diğer İran dillerindeki metinlerin yayınında genellikle transliterasyon yöntemi uygulanmış ve transkripsiyona gidilmemiştir. A. von Gabain'e Uygurca metinlerde de bu yöntemi izlemesi önerilir. Ancak o, transkripsiyonda israrcı olur.

$\mathrm{Bu}$ görüşleri dikkate alan Klaus Röhrborn da 1970'li yılların başında, Giessen'de, Uygurca Sözlük'ün hazırlıklarına başlar. Sözlüğün amacı bir thesaurus oluşturmaktı. Yani bu çalışmada Uygurca üzerine yayımlanmış her metnin sözvarlığını kapsayacak bir çalışma olması hedeflenmişti. Bu amaçla başlayan çalışmanın ilk sonucu 1977 yılında yayımlandı. 72 sayfalık ilk fasikülde sözlüğün hazırlanış yöntemi, kullanılan transkripsiyon alfabesi, göz önünde bulundurulan kaynaklar ve kullanılan kısaltmalar ilk 39 sayfayı oluşturmuştu. 1998'e kadar yayımlanan 6 fasikül toplam 446 sayfa olup iki harfi içeriyordu: a ile başlayan kelimelerin tamamı ile $e$ (burada $\ddot{a}$ ) ile başlayan kelimelerin eryek'e ("parmak") kadar olan k1sm1.

Her ne kadar sözlük, yayımlanmış çalışmaların tümünü kapsama amacıyla hazırlanmıș olsa da, o dönem için henüz yayımı tamamlanmamıș, kapsamlı metinleri de içerir. Örneğin eski Uygurca Altun Yaruk Sudur'un o günlerde henüz akademik bir neşri tamamlanmamıştı. Sözlükte yer verilen örnekler arasında Altun Yaruk Sudur, eski Uygurca Xuanzang Biyografisi ve Maitrisimit'e ait örnekler önemli bir yere sahiptir. K. Röhrborn bu eserlere ait örnekleri kendisi hazırlayarak sözlüğe katmıştır. 
Sözlük latin harflerine dayanan bir transkripsiyon sistemiyle sıraya konmuş, bu şekilde yayına hazırlanmıştır. O güne kadar eski Uygurcanın yazımında kullanılan klasik "Berlin transkripsiyon sistemi"nden ayrı olarak, deyim yerindeyse fonetik bir sisteme göre hazırlanmıştır. Yani Qaf/kef, ga/ge ayrımı yapılmaksızın, yalın olarak tek bir $k$ ve tek bir $g$ kullanılmış, $g / \dot{g}, \mathrm{k} / \mathrm{k}$ şeklinde kullanıma gidilmemiş, agır yazarken de $g$ kullanılmış $(a \dot{g} \iota r$ değil), egrig "eğri” yazarken de $g$ kullanılmıştır.

Sözlüğün hazırlanışında 9 ünlü harf kullanılmıştır: $a-\ddot{a}-e-l-i-o-$ $\ddot{o}-u-\ddot{u}$. Oysa o güne kadarki transkripsiyon sistemleri (Sir G. Clauson'un sözlüğü hariç) Eski Türkçe için 8 ünlü harfe yer veriyor, kapalı $e$ 'yi kullanmıyordu. $c, s, j$ sesleri $\check{c}$, $\breve{s}$, $\check{z}$ harfleri ile gösterilirken $\imath$ harfi önceki yayınlardan farklı olarak $\ddot{i}$ değil de $\imath$ ile gösteriliyordu. Art damak $n$ 'si ise $\eta$ ile gösteriliyordu.

Röhrborn, sözlügün hazırlanış yöntemini alkış maddesi üzerinden kısaca tanıtmıştır:

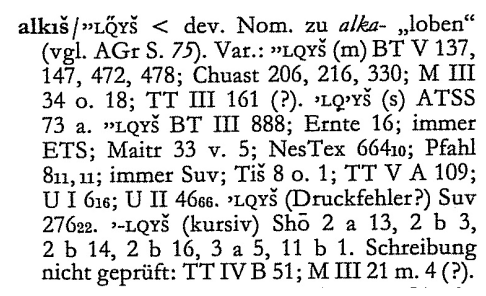

Latin harfleri ile madde başına yer verildikten sonra küçük-büyük harfler ile yaygın imlası transliterasyon harfleriyle gösterilmiştir. Bu yolla $k$, $g, s, s, n$ vb. harflerinin yazımında ayırt edici noktaların var olup olmadıkları, varsa kaç adet nokta kullanıldığ 1 görülmektedir. Buna göre alkış kullanılırken üzerinde iki nokta bulunan $q$ harfi kullanılmıştır. Eğer bu yazımın dışında başka yazım türleri (burada: "LQYŠ) veya Uygur yazısı dışında Mani ve Brahmi harfleri ile yazılmış şekilleri de varsa bunlar (m) ve (br) ile gösterilmişlerdir. Kursiv ve Soğud harfleri ile yazılanlar da (kursiv) ve (s) ile ayırt edilmişlerdir. Kelimenin kökeni veya türediği gövde de kısaca gösterilmiş, uzun etimoloji bahislerine girilmemiştir. Ancak kısa da olsa, her kelime için geçmişte çeşitli otoritelerin etimoloji önerileri, sırasıyla (W.) Bang, (Sir G.) Clauson, (G.) Doerfer ve (E.) Sevortyan'a göre, 1990 sonras1 da (M.) Erdal'a göre gösterilmiş, yeri gelince bu etimolojilerin çok kısa düzeltileri, eleştirileri de yapılmıştır. Bir thesaurus'a uygun olarak kelimenin geçtiği kaynaklar sırasıyla zikredilmiştir: 


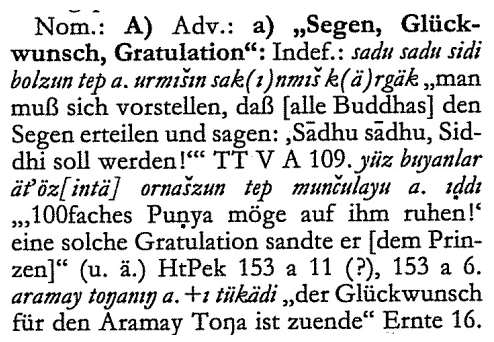

$\mathrm{Bu}$ giriş kısmından sonra örneklerin işlenmesine geçilmiş, kelimenin hemen hemen her yayındaki farklı anlamı, kullanımı örnek cümleler içerisinde sıralanmıştır. Bu aşamada eğer bir sözcük hem ad, hem belirteç hem de sıfat olarak kullanılmışsa ayrı alt maddeler içerisinde örneklerine yer verilmiştir. Maddenin sonunda ise "bağlamı açık olmayan kelimeler" ile yazmanın hasar gördüğü, kelimenin öncesi veya sonrası kayıp olduğu durumlar "bağlamsız, bağlam dışı" olarak gösterilmiştir (aşağıda sırasıyla C ve $\mathrm{D}$ maddeleri).

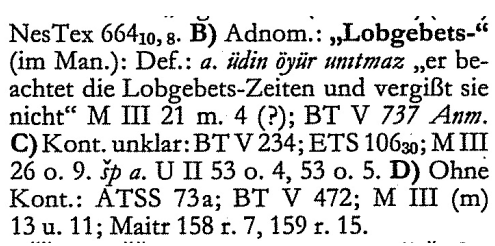

Sözlükte, yararlanılan kaynaklardaki okuma, anlamlandırma hatalarından tutun da hayalî okumalara varana kadar her tür düzelti madde içi ve madde başlarında gösterilmiştir.

Sözlüğün 1979, 1981, 1984, 1994 ve 1998'de çıan 2-6. fasiküllerinde, geçen süre içerisinde çıkan her yeni yayın sözlüğe eklenmiş, yeni yayınlar fasiküllerin başında veya sonunda kısaltmaları ile beraber yer almışlardır.

1998'deki 6. fasikülden sonra sözlügün devamı için yeni bir proje hazırlanmıştır. Bilimler Akademisi yeni projenin önceki sözlükten farklı olması gerektiğini belirtince yeni sözlüğün fiiller, isimler ve alıntı kelimeler şeklinde 3 ayrı şekilde çıkartılmasına karar verilmiştir. Bu yeni projenin ilk ürünü 2010 yılında fiil cildinin ilk cildi olarak çıkmıştır: Uigurisches Wörterbuch. Sprachmaterial der vorislamischen türkischen Texte aus Zentralasien. Neubearbeitung. I. Verben. Band 1: $a b-$ - äzüglä-, Stuttgart. İsim bölümünün ilk cildi ise 2014 yılının sonunda çıkacaktır. Bu yeni çalışmanın önemli bir başka özelliği de madde başlarının tanımın iki dilli, Almanca ve Türkçe olmasıdır. Bu yenilik A. V. Gabain'in 1941'deki gramerinin sözlük kısmını çağrıştırır. 
600'e yakın çalışmanın, yayının, incelemenin değerlendirildiği sözlükte thesaurus uygulamasından vazgeçilmiştir. Önceki yayında kelimenin işlevlerine dayanan çok ayrıntılı alt madde ayrımları bu yayında bir ölçüde azaltılmıştır. Aşağıda sözlükten bir madde ve iki dilli olarak madde tanımı örneği verilmiştir:

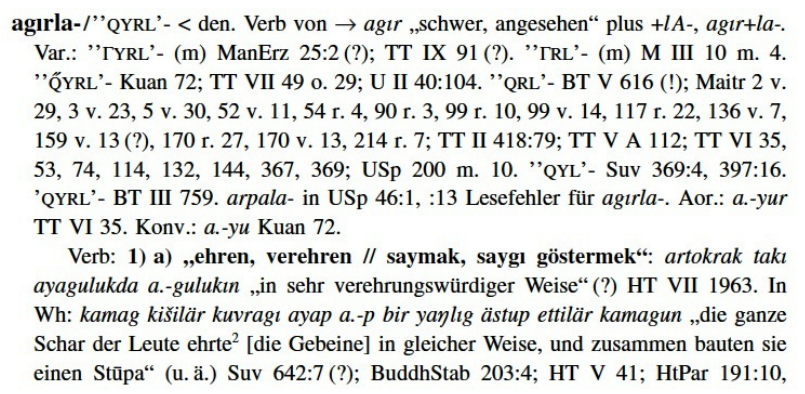

Uygurca üstadı Klaus Röhrborn'un yayımlanmış çalışmalarına şu adreslerden ulaşılabilir:

Jens Peter LAUT-Mehmet ÖLMEZ, "Doğumunun 75. Yılında Klaus Röhrborn", Türk Dili, C. CII, S. 733, Ocak 2013: 78-87; http://www.tdk.gov.tr/images/20130119.pdf:

http://de.wikipedia.org/wiki/Klaus_Röhrborn.

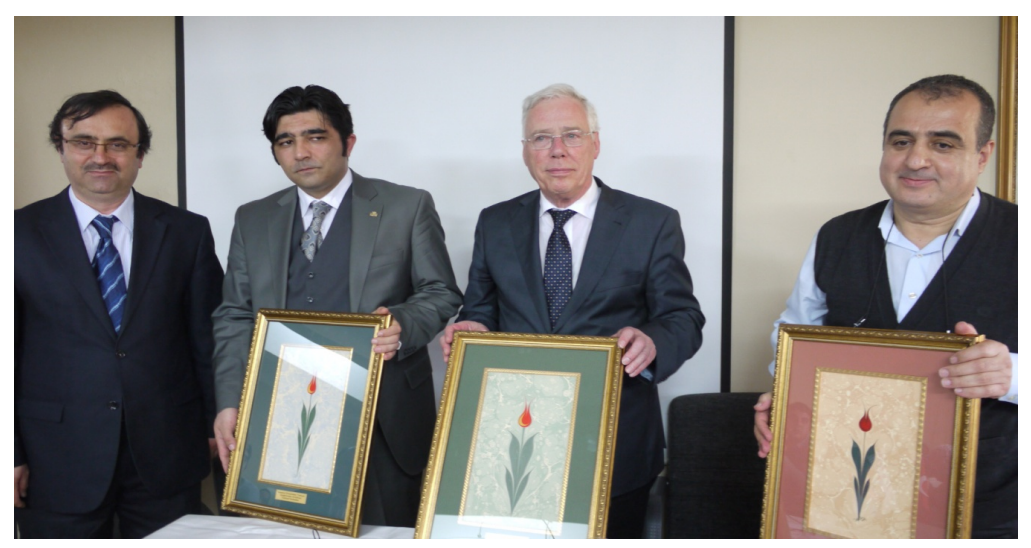

Türkiyat Sohbetleri'nin yedinci konuşması, 30 Nisan 2014 tarihinde Erciyes Üniversitesi Edebiyat Fakültesi Türk Dili ve Edebiyatı Bölümü Öğretim Üyesi Prof. Dr. Mustafa Argunşah'ın "Kodeks Kumanikus Üzerine Düşünceler" konulu konferansıyla gerçekleştirildi. 
Kodeks Kumanikus'un tıpkıbasımının görüntüleri eşliğinde sunduğu konferansa eseri tanıtarak başlayan Argunşah, eser üzerinde yapılan bilimsel çalışmaların tarihinin 1828 yılına kadar uzandığını, J. Klaproth'un eseri tanıtarak bazı bölümlerini yayımladığı 1828 'den günümüze kadar metnin birkaç defa yayımlandığını; ses, biçim ve cümle bakımından incelendiğini belirtti. Eserin değişik bilim insanları tarafından defalarca yeniden okunmasinın ve yayımlanmasının sebebini, metnin okunması ve anlamlandırılmasındaki zorluklardan kaynaklandığını söyleyen Argunşah, aradan geçen iki asra yakın zamana rağmen Türkiye'de eserin metninin yayımlanmamış olmasının büyük bir eksiklik olduğunu ifade etti.

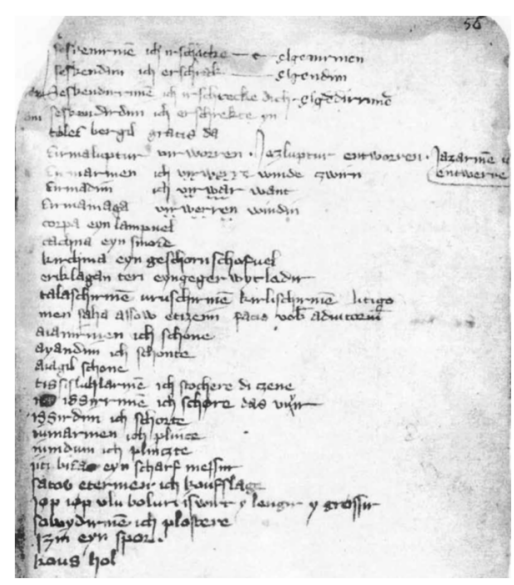

Argunşah, konuşmasında eserin eldeki tek özgün yazmasının İtalya' da Venedik Saint Marcus Kütüphanesi'nde bulunduğunu, J. Klaproth'un 1824 yılında Venedik kütüphanecilerinden birisine Saint Marcus Kütüphanesi'ndeki asıl Kodeks'in birinci bölümünün bir kopyasını yaptırıp bu nüsha üzerinde çalışarak Arap harfli transkripsiyonları ve Fransızca ilaveleriyle 1828 yılında yayımladığını, bu ikinci nüshanın Floransa Laurenziana Kütüphanesi'nde, Ms. Ashburnham 1584 seri numarası ile kayıtlı olduğunu ifade etti. Eserin İtalyan ve Alman bölümlerini geniş olarak tanıtan Argunşah, Türkiye'de Kodeks Kumanikus'un muhtevasını tam olarak anlatan bir yayının bile bulunmadığını, yapılan kimi çalışmaların G. Kuun'un 1880 yılındaki metin yayımıyla Grönbech'in 1942 'de yayımladığı Sözlük'e dayandığını, kendilerinin bu eksikliği görerek meslektaşı Doç. Dr. Galip Güner ile eseri yayımlamaya karar verdiklerini, bu konudaki çalışmalarını sürdürdüklerini belirtti. Türk dili, özellikle de kültür tarihi için son derece önemli olan bu eser Türkiye'de yayımlandığında, önemli bir boşluğun dolacağını söyledi. 
Argunşah, daha sonra Kodeks Kumanikus'un yazılış tarihi üzerindeki tartışmalara değindi. Kendi düşüncesinin de bu eserin İtalyan bölümünün 1292-1294 yılları arasında, Alman bölümün ise 14. yüzyılın ilk yarısında yazıldığı yönünde olduğunu belirttikten sonra eserin yazıldığı yer konusundaki tartışmaları hatırlattı. İtalyan bölümünün büyük bir ihtimalle İtalyan kolonilerin yerleştiği Karadeniz'in kuzeyinde Kırım civarında bir yerde, Alman bölümünün ise misyonerlik faaliyetlerinin yürütüldüğü Kıpçak şehirlerinin birinde yazılmış olabileceği kanaatinde olduğunu söyledi.

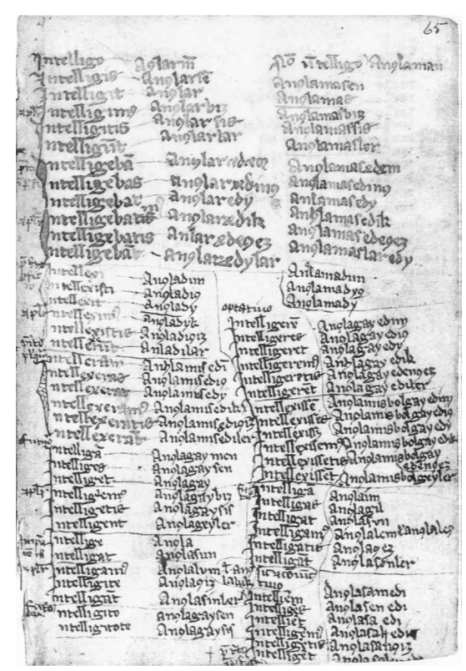

Argunşah, eserin yazılma sebebi olarak ise şunları söyledi: "Eserin Latince-Farsça-Kıpçakça bir sözlük olan İtalyan bölümünün yazılış amacı; ticaret dilinin Farsça olduğu İlhanlılar Devleti ve ticaret dilinin Kıpçakça olduğu Altın Ordu Devletleriyle ticaret yapan ve Latince-İtalyanca konuşan İtalyan tüccarların günlük hayatta ve ticarette Fars ve Kıpçak kökenli kişilerle ilişkilerini kolaylaştırmaktır. Eserde hedef kitle İtalyan tüccarlardır. Bunlar, günlük hayat yanında ticaretle ilgili de zengin bir kelime hazinesine sahip sözlükten öğrendikleri Farsça ve Kıpçakça sayesinde hem Farslarla hem de Kıpçaklarla rahatlıkla ilişki kurabilecek ve ticaret yapabileceklerdir. Sözlükte Latince sütunun başta bulunması ve kelimelerin bu dilin alfabetik sırasına göre dizilmiş olması da Latince konuşanlara hitap edildiğini göstermektedir. Alman bölümünün yazılış amacı ise, Kıpçaklar arasında Hristiyanlığı yaymak, bu dinin temel duaları, vaazları ve ilahilerini Kıpçaklara öğretmek olmalıdır."

Eserin dilini de değerlendiren Argunşah, Kodeks Kumanikus'un Altın Ordu sahasında yaşayan Kıpçakların diliyle yazıldığını, bu dilin Kıpçakçanın 
Kuman lehçesi olduğunu belirtti. Kuman lehçesinin kendi içinde homojen olmadığını, eserin İtalyan ve Alman bölümlerinin farklı ağızlarla yazıldığını, özellikle başka bir nüshadan istinsah edilmiş olan İtalyan kısmında metne sonradan ikinci ve üçüncü kişilerce müdahale edildiğini, kimi kelimelerde değişiklikler yapıldığını söyledi. Eserin imlasının her iki bölümde de kendi içinde tutarlı olmadığını, müstensihlerin kendileri için yabancı olan Türkçe ve Farsçanın bazı seslerini iyi tanınmadığının açıkça belli olduğunu, bu yüzden de çeşitli harflerin yaklaşık değerlerinde yer yer sapmalar görüldüğünü belirten konuşmacı, eserin dilinin metinde "Tatarça" ve "Tatar til" olarak gösterildiğini, Latince sözlerde ise Komanca (Kumanca) olarak belirtildiğini ifade etti.

Argunşah, konuşmasının önemli bir bölümünü eserin muhtevasına ayırdı. Kodeks'in bölümlerini tek tek sayfa numaralarıyla birlikte anlatarak İtalyan bölümündeki 40 kelime kümesini oluşturan kelimeleri liste hâlinde gösterdi. Alman bölümünü oluşturan bilmeceler, ilahiler, dinî metinler üzerinde duran Argunşah, eserin 75a-75b sayfalarındaki notalı bir ilahiye dikkat çekerek, Türk müzik tarihinde ilk defa Türkçe bir metnin bu eserle notaya alındığını söyledi. Konuşmacı daha sonra Kodeks Kumanikus'un Türk kültür tarihindeki yerine dikkat çekerek eserdeki kumaş adlarıyla ay adlarının olduğu bölümler üzerinde durdu ve ay adlarının ilk defa bu eserde sıralandığını belirtti.

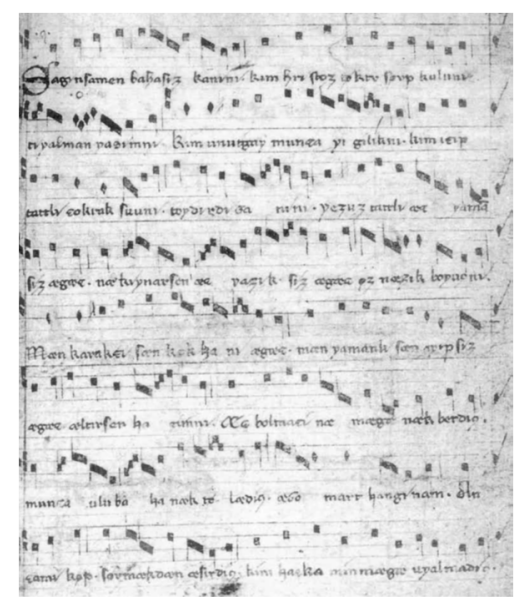

Konuşmanın sonraki bölümünde eser üzerinde yapılan çalışmalar tanıtıldı. 1880 yılında ilk defa tam metni yayımlayan C. G. Kuun'dan beri farklı coğrafyalarda bilim insanlarının eseri daha doğru ve anlaşılır hale getirmek için çaba sarf ettiklerini belirten Argunşah, eser üzerinde G. Kuun, 
W. Bang, A. N. Samoyloviç, D. Rasovkiy, W. Radloff, K. Grønbech, T. Kowalski, T. Halasi Kun, V. Drimba, A. von Gabain, D. Drüll, A. Tietze, A. Garkvets gibi birçok yabancı bilim adamının yayınlar yaptığını; Türkiye'de ise Ahmet Caferoğlu ile Saadet Çağatay'ın çalışmalarının önemli olduğunu belirtti. Son yıllarda Orçun Ünal tarafından eserin birinci bölümünün metni üzerinde bir yüksek lisans tezi hazırlandığını fakat bu çalışmanın henüz yayımlanmadığını söyledi.

Konuşmasında eserin dil özellikleri üzerinde duran Argunşah, önce ses, daha sonra da biçim ve söz dizimi özelliklerine değindi ve söz varlığından bahsetti. Argunşah, konuşmasının önemli bir bölümünü eserin imlasına ayırarak şunları söyledi: "Eserin zengin kelime hazinesi Türkçenin sözlüklerine büyük katkılar yapmakta, tarihî Türk lehçelerine ait eserlerde karşılaştığımız fonetikle ilgili birçok sorunun çözümüne yardımcı olmaktadır. Fakat her sorunu çözdüğünü de iddia edemeyiz. Ayrıca Türkolojide genel olarak, eserin Latin alfabesiyle yazılmış olması sebebiyle ünlülerle ilgili bütün fonetik problemlerin çözümüne kaynaklık edeceği kanaati yaygındır.

Arap harfleriyle yazılan Orta Türkçe dönemine ait metinlerin çözümlenmesine hiç kuşkusuz yardımcı olmaktadır. Ama yine de Kodeks Kumanikus'un her sorunu çözen sihirli bir anahtar olduğu asla düşünülmemelidir.

Orhun, Uygur ve Arap alfabesiyle yazılmış metinlerde kimi zaman tereddüt ettiğimiz o/u, ö/ü, e/è/i seslerinin Latin alfabesine aktarımında kimi kolaylıklar sağlasa bile bu her zaman mümkün değildir. Eğer, eserin yazımında her ses için bir harf kullanılmış olsaydı tarihî metinlerdeki fonetikle ilgili sorunları kolayca halledebilirdik. Fakat bazen bir sesi karşılamak için iki, üç, hatta altı harfin kullanılmış olduğu dikkate alındığında bir kısım sorunların devam ettiği görülmektedir. Kimi kelimelerin okunuşunda eser içinde de sorunlar bulunmaktadır. 


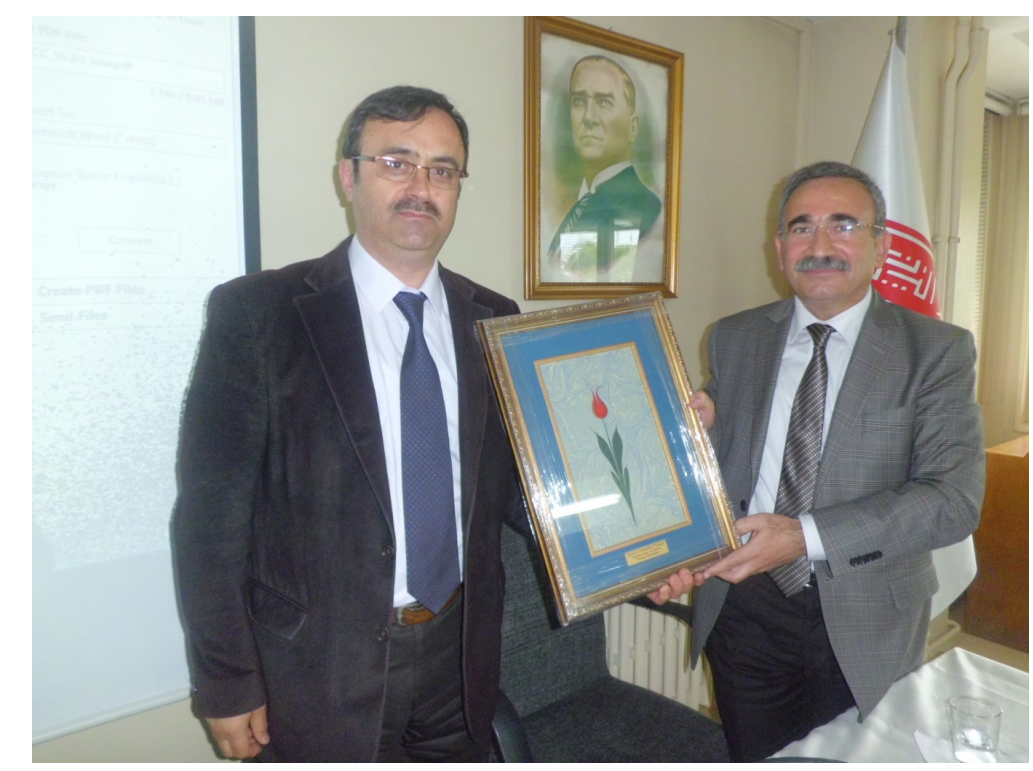

Türkiyat Sohbetleri'nin 2013-2014 dönemi son konuşması, 28 Mayıs 2014 tarihinde Yeditepe Üniversitesi Felsefe Bölümü Öğretim Üyesi Prof. Dr. Mehmet Bayrakdar'ın konuşmacı olarak katılımıyla gerçekleştirildi. Prof. Dr. Mehmet Bayrakdar, "Türkler ve Medler" başlıklı konuşmasında şu konulara temas etti:

"Medler M.Ö 4500 yıllarında Sakalardan ayrılarak bugünkü Azerbeycan bölgesinde Mata (Mada) adındaki önderlerinin başkanlığında bir beylik olarak tarih sahnesine çıkmışlardır. Bugünkü Hemedan'ı başşehir ilan ederek M.Ö 2500 yıllarında I. Dahaku başkanlığında Med İmparatorluğu denen bir imparatorluk kurmuşlar ve uzun geniş bir coğrafyada, birçok kavme hükmetmişlerdir.

Son Med kralı Astiyages'ın (Efrasyap, Alp Er Tunga) kızından torunu I. Cyrus M.Ö 522 veya 520 yıllarında bir ihtilalle dedesini tahttan ederek, İmparatorluk Pers İmparatorluğu adıyla I. Darius'un Ahamenid Devleti'ni kurmasına kadar aynen devam etmiştir. Pers İmparatorluğu denmesinin nedeni I. Cyrus'un babası Cambyse'in Persli olmasındandır. 


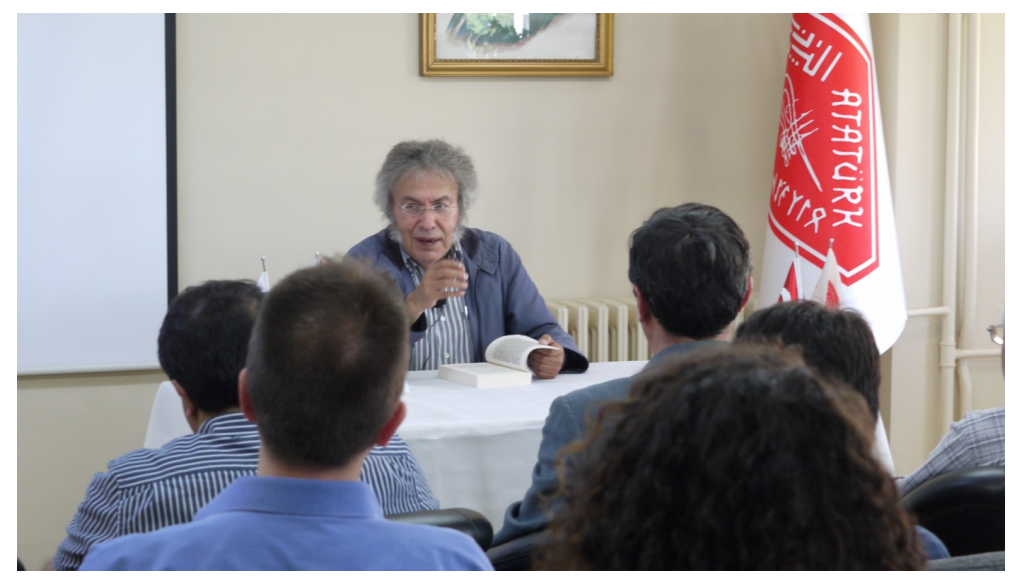

Başta Babilli tarihçi Berosus (M.Ö. 3.yüzyıl) olmak üzere bütün eski tarihçiler ile özellikle de 19. yüzyılda Persepolis ve Asur yazıtlarını çözen E. Norris, Fr. Lenormant, Sir H.C. Rawlinson, J. Oppert, I. Taylor, N L. Westergaard, F. de Saulcy ve M. S. Zaborowski gibi Batılı dilciler, tarihçiler ve antropologlar Medlerin dil, din ve irk olarak Turani (Saka, Tatar,Türk) olduğunu ortaya koymuşlardır. Bu görüş baskın bir görüş olarak 1935-1940 yıllarına kadar devam etmiştir. Ancak bir kısım Batılı papaz tarihçiler ile Ermeni tarihçileri, 6. yüzyıldaki bir papazın Medler'e İranlı demiş olduğu iddiasıyla Medlerin İranlı olduğu iddiasında bulunmuşlardır. Özellikle 1950 yılından itibaren devrik İran şahı Muhammed Rıza Pehlevî’nin 17 kadar batılı oryantalisti toplayarak 1smarlama bir İran tarihi yazdırmasıyla sadece Medler değil; bugünkü İran bölgesinde yaşamış bütün eski kavimler İranlı yapılmıştır. İşte bu tarihten sonra Medlerin İranlı iddiası yaygınlık kazanmıştır. Ne yazık ki, Türk tarihçileri de bu yanlış görüşün tekrarlayıcısı olmuşlardır. Oysa, diğer bazı eserleri bir kenara bırakarak sadece tarihin babası kabul edilen Herodot'a bile bakmak yeterlidir; çünkü o da Medlerden bahsetmiş ve Medlerin kan ve irk olarak Perslerden ayrı olduğuna vurgu yapmıştır. Medleri, Herodot'a dayanarak Aryan yapan Batılı tarihçilerin sahtekârlıklarını da görmüş olacaklardır. Çünkü Herodot'un Tarihi'ni modern Batı dillerine çevirenlerden bazıları, Medlerin Med adıyla anılmazdan önceki adlarının Arioi (Arii) olduğunu belirttiği bu sözcüğ̈̈, Aryan yaparak Herodot'un da Medlere Pers dediği anlamını çıkaranlara karşı notlar düşerek Arioi'nin Aryan olmadığını belirtmiş olduklarını da göreceklerdi. Hatta Firdevsî gibi Ortaçağ İranlı tarihçiler, Medleri Med adı ile değil "Kayân" ve "Kayânî" adıyla anmışlardır. Firdevsî̀nin Şehname'sinde Keykavus, Keykubad gibi adlarla anlattğı Med veya Kayânî 
krallarının bu adları sanıldığı gibi Farsça değildir. Pehlevice telaffuza göre söylenmiş Medce veya Türkçe kökenli adlardır. Her ne kadar Firdevsî ve diğer Ortaçağ İranlı tarihçiler Kayânîleri anlatırken, Piştad krallığı dedikleri tamamen efsanevi krallar zincirinin bir devamı göstererek onların zımnen de olsa İranlılığına vurgu yapmak istemişlerdir. Son dönem Ahamenidleri ve Sasaniler de Medlere Kayânî demekteydiler. Çünkü "Kay" sözcüğü, İranlıların adlandırılmasıyla Kayânilerin, eski Yunanların ve Batılıların adlandırmasıyla Medlerin krallık unvanıdır; anlamı da "Bey" veya "Bay" demektir. Bilinen hiçbir Pers veya Ahamend dönemi İran asıllı kral Kay sanıyla anılmamıştır. Türkler tarih boyunca bu Kay unvanını kullana gelmişlerdir. Bilindiği gibi, Osmanlıların da boyu "Kayı" adını taşır; aslında bu adın "Kayı" değil, "Kay " olması gerekir; tartışmasını burada yapacak değiliz. Medlerin İranlı olamayacağını başka kaynaklar da gösterir. Örneğin Tevrat; Tevrat'ın Yaratılış (Genesis) kitabında Hz. Nuh'un üç oğlundan insanlığın yeniden türeyişi anlatılırken, Med ve diğer Türk soyluların adı geçerken, onlarla birlikte, ne Pers ve ne de İran adı geçer. Çünkü Tevrat'ın bu kitabı yazılırken bölgede İranlılar yoktu; bazı Batılılara göre söz konusu kitabın yazılışı M.Ö. 1500 yılına kadar gitmektedir. Eski kaynaklarda Medler hakkında anlatılan dini ve millî gelenekler ve görenekler de Medlerin Türk soylu olduğunu göstermektedir; bunlardan birisi örneğin "Kan Kardeşliği” olayıdır. Med uygarlığı başta Persler olmak üzere Asurluları, Babillileri, Yunanlıları ve Romaları büyük oranda etkilemiştir.”

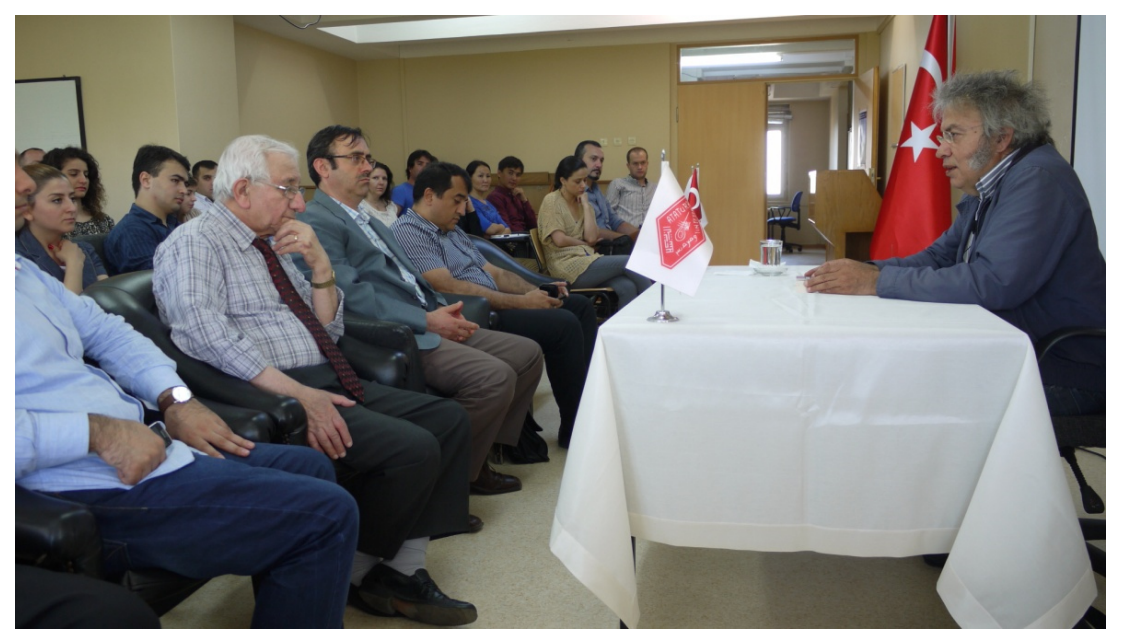


